\title{
THE UNIVERSE REEF
}

Up, up and away.

\section{BY TOBIAS BUCKELL}

$\int$ ackson buckles his leathers tighter and pulls on a fur. "The height causes that cold," he shouts. "We're like mountaineers!"

I want to flee the bitter cold and escape the wind, which seems to pierce my skin and scrub my bones. But I don't want to miss seeing the Stone Table with my own eyes.

We're standing on a catwalk that juts out from the skin of the airship and connects to the giant propellers on either side of the midbelly area. The large blades are still, as the captain has found us a current of air. To save fuel we're drifting, occasionally correcting our course when engines to the rear of the whalelike lighter-than-air machine roar to life.

Underneath our feet: a mile of air. And then below that is the brown, rippling mass of the Reef.

Once upon a time, there was no Reef. The world looked vastly different. There are preserved pictures of this time, spirited away from the museums before they fell to the reef. But more than we can ever remember will always be trapped where they were stored in great cities of legend like Paris, London or Washington, where great men once had grand adventures.

What history, legend and archaeologists agree on was that something split the sky asunder. And the debris that rained down from above was not just meteorite. Something else struck the earth and the water.

It was a reef. Tiny beings deposited tiny skeletons that were built on and ossified until an entire ecosystem accreted. And more alien organisms, hidden away inside the remains of the rocks that fell, flowered around the reef. The alien flora marched across the ground, but left the oceans alone.

The Reef ate cities as it spread across the world, seeking out metal with a hunger than no one could quench.

Our ancestors fought it. Men from a different time, from those old nations, with those old technologies, unleashed hell upon the Reef. And sometimes they would slow it. Sometimes they would even kill it.

But it always came back.

It was the Reef. Inexorable and implacable. It reshaped the world.

Jackson Smithik is an adventurer. Those thick dreadlocks of his are growing grey with age, and his face is leathery from exposure to the Sun. He was the first person, post-Collapse,

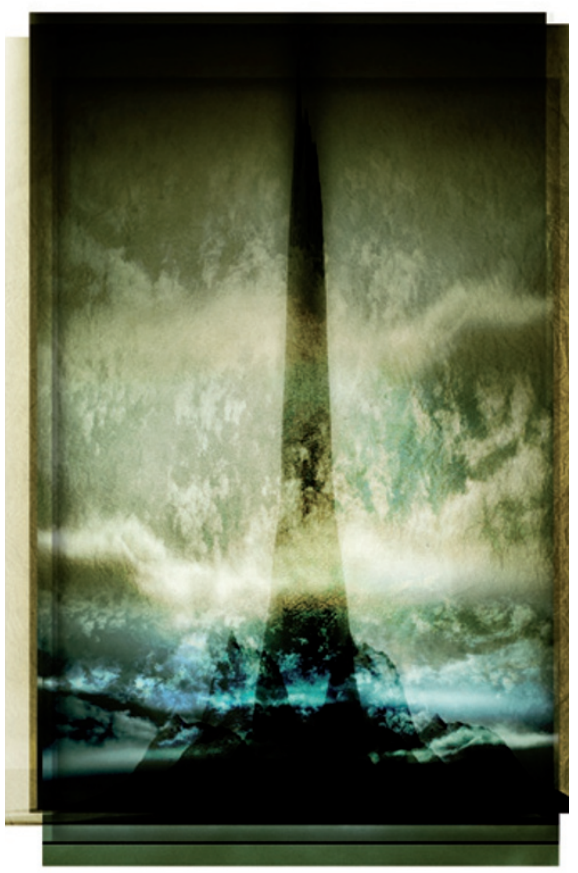

to sail across the Atlantic, back to skirt the Reef-choked coasts of Africa, down to the cape, and then sail out to make contact with the Indian and then Pacific Islands.

Because it was only the smaller islands that survived the Reef, isolated by the ocean and far from the Reef's continental creep.

Seventy years after his teenage captaincy and exploits, Smithik's Jamaican Clippers roam the world's oceans, connecting the world. And now, thanks to the advances of steam and steam-powered airships by the Icelandic Empire, Smithik Transport ships explore the skies.

“There it is," Smithik shouts. A grey wall rises out of the Reef, which covers what was once the land of South America. And above the Stone Table rises The Tower.

I follow the bulk of the structure. It is too much. It is a mountain in the distance that tapers off into a needle that pierces the clouds. And keeps going.

"This is what the Reef was for," Smithik yells into my ear. His eyes gleam.

Over some strong Blue Mountain coffee, back inside where it was warm, Smithik $\rightarrow$ NATURE.COM

Follow Futures on

Facebook at:

go.nature.com/mtoodm tells me: "Pre-Reef scientists had a theory called panspermia: they believed life on Earth was caused by small organisms aboard comets thrown from col- i⿱ lisions in other solar systems crashed down to seed life here, and maybe elsewhere.

"So a follow up infection, that's not so hard to believe, yeah?"

I nodded and kept notes. I'd been paid to document his first trip to actually step onto Stone Table since Smithik's adventurers had found it and reported back.

We land on the massive Reef-grown artificial stone structure and moor the airship. The joint Japanese and Hawaiian expedition group, and the Icelandic scientists who'd beaten them there, greet us.

Pictures are taken with the excited scientists and the man who had funded the first expedition to Stone Table, found when Caribbean telescopes had spotted the slowly selfassembling tower to space.

"We can't say if the Reef is designed to create The Tower, programmed by some distant intelligence," the scientists tell Smithik as I scribble. "It could just be the way the Reef reproduces, creating a way to fling its spores back into space."

"But the Stone Table, and the grooves in The Tower, they'll allow us to climb it with a machine into space? Doesn't that prove it's made for intelligence?" Smithik asks.

"Sometimes nature builds something something else can use. Maybe it's hoping we'll spread Reef spore as we use this to get into space."

"As if we were bees," Smithik nods.

Late in the night I stand with Smithik at the base of The Tower, looking up at the night sky.

"Pre-Reef men once walked on the Moon," he says.

"And you think we'll go back?"

"Whether we're part of some galactic ecosystem that the Reef is just a spore of, or whether something designed it, the more we explore out there the more we'll understand what happened down here."

The great adventurer died that night. But his spirit lives on in the Smithik Ascender, a plan by the international scientists to build a steam-powered climber that will ascend The Tower to space.

What we will find, no one knows.

Tobias Buckell was born in the Caribbean but now lives in Ohio. He is the author of multiple novels and can be found online at www.TobiasBuckell.com. 